咽頭喉頭頸部食道切除術を必要とした甲状腺癌の 3 例

\author{
金沢大学第 1 外科（主任：渡辺洋宇教授） \\ 安田保大村健二浦山博 \\ 石田文生川上和之渡辺洋宇
}

甲状腺分化癌は予後良好な疾患であるが，周辺缄器に厇範に浸潤した症例にはそれら の合併切除が必要となる.今回われわれは, 甲状腺全摘, 咽頭喉頭頸部食道切除, 遊離 空腸移植による形部食道再建（以下本術式と略）を必要とした気管, 頸部食道浸潤を伴 5 甲状腺癌の 3 例を経験したので報告する。

症例 1 は70歳女性. 気管食道浸潤を伴 5再発甲状腺癌に対し本術式を施行した。術後, 合併症を認めなかったが，8カ月目に甲状腺癌縦隔再発により死亡した。症例 2 は 57 歳 女性，孤立性肺転移，気管食道浸閏を伴 5甲状腺癌に対し本術式及び肺部分切除を施行 した. 術後一過性に䩧下困難を認めたが, 術後 3 年の現在ほとんど愁訴なく快適な日常 生活を送っている。症例 3 は74歳女性, 多発性肺転移, 気管食道浸潤を伴 5 甲状腺癌に 対し本術式を施行した。街後 2 カ月の現在呼吸困難は消失し, performance statusの著 明な改善をみた。

妻引用語: 甲状腺癌, 咽頭搌頭頸部食道切除, 遊離空腸移植

はじめに

遊離空腸移植による食道再建は，有茥腸管や筋皮弁 を使用する方法に比べて侵畩が少なく，合併症の頻度 す低い優れた術式であることが認められている。今回 われわれは, 甲状腺全摘, 咽頭喉頭頸部食道切除, 遊 蜼空腸移植に上る頸部食道再建（以下本術式と略）を 必要とした気管, 頸部食道浸潤を伴ら甲状腺癌の 3 例 を経験したので報告する。

$$
\text { 症例 }
$$

症例 $1: 70$ 歳, 女性.

主訴：呼吸困難, 喳下困難.

既往歷：1987年膀胒癌に対し膀胼全摘及び回腸導管 造設術を施行.

現病歴：1988年 1 月嗄声が出現し, 当院耳鼻咽喉科 を受診, 甲状腺癌（JT4，JN1，M0）と診断された. 4 月 9 日両側反回神経麻瘏に対し気管切開術, 4 月 25 日甲状腺癌に対し甲状腺严全摘術を施行された。腫湯 は被膜をこえ，気管，食道に浸潤していた。病理組織 学的には乳頭癌で甲状腺切除断端に癌が認められた。 9 月中旬呼吸困難, 㖓下困難が出現し, 当科紹介入院

1992年 5 月 1 日受付 1992年11月24日採用
となった。

経過：諸検查にて気管食道に浸潤した再発甲状腺癌 と診断した。10月 7 日本術式を施行。両側の modified radical neck dissection (MRND) を行った。病理組 織学的には未分化転化を伴う乳頭癌であった，術後の 食道造影検查では，吻合部に狭窄や造影剤の漏出を認 めず，通過は良好であった。食物の無下も容易となり， 順調に回復し，11月24日に退院したが，1989年 6 月甲 状腺癌の縦隔再発により死亡した。

症例 $2: 57$ 歳, 女性.

主訴：頸部腫瘤.

現病歴：1989年 6 月左側頸部に隀瘤を触知し近医受 診, 甲状腺腫場を指摘され, 手術目的で当科紹介入院 となった。

経過：頸部 CT 検査では気管食道へ厷範に浸潤した 甲状腺腫覆を認めた。食道内視鏡では食道の压排を認 め，気管支内視鏡では気管への直接浸潤を認めた，胸 部 X 線写真で右下葉に結節状の陰影を認め, 胸部 CT 検査, ${ }^{201} \mathrm{~T} 1$ スキャンにて坬立性肺転移が強く疑われ た。以上の検查より孤立性肺転移を伴 5，気管及び食 道へ浸潤した甲状腺癌（JT4, JN1，M1）と診断， 7 月 7 日本術式を施行，あわせて両側の MRNDを行っ 
た。術後の食道造影検査では吻合部に狭窄や造影剂の 漏出を認めず，通過は良好であった。術後 1 カ月ほど 髙下困難と移植腸管内容の逆流を認めたが，その後軽 快した.9月11日肺右葉 S8の孤立性肺転移に対し肺部 分切除術を施行, 病理学的に甲状腺乳頭癌の転移之確 認された。その後の経過は良好で，10月16日退院，10 月31日当院核医学科にて内照射を施行, 術後 3 年の現 在ほとんど愁訴なく，快適な日常生活を送っている。

症例 $3: 74$ 嵗, 女性。

主訴：嗄声。

現病歴：1985年より嗄声を認めていた。1991年12月 燕下困難，呼吸困難が出現したため近医受診，甲状腺 畽瘍を指摘された．12月25日手術目的で当科紹介入院 となった。

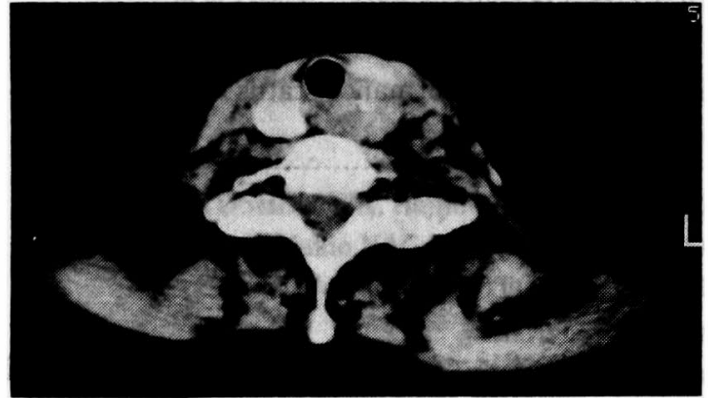

図 1 顠部 CT 検査：甲状腺左葉を中心とした直径3 $\mathrm{cm}$ の甲状腺腫瘍を認める。畽瘍之気管, 食道の境界 は不明瞭で浸潤が疑われる。

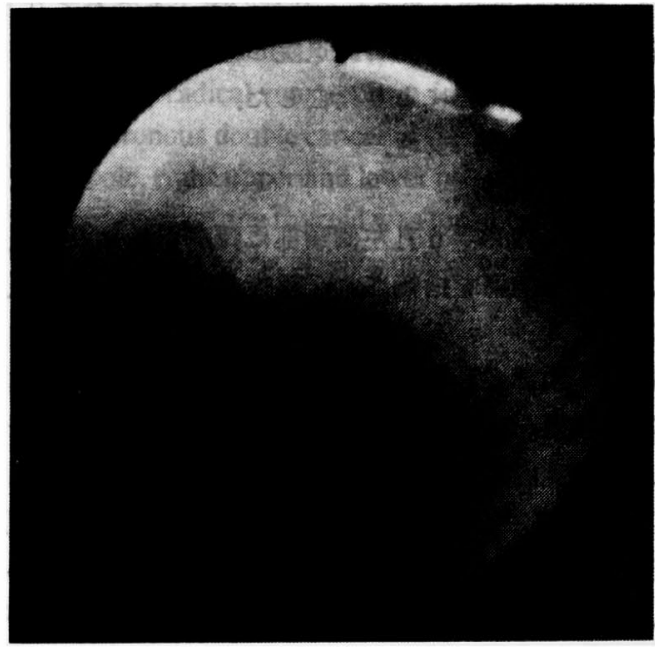

図 2 上部消化管内視鏡検査：頸部食道は腫瘍により 圧排されている。
経過：頸部 CT 検査にて気管食道に厇範に漫潤した 甲状腺腫場を認めた（図 1 )。内視鏡検查では食道は周 囲から正排されており（図 2)，食道造影検查でも腫汮 による頸部食道の圧排像を認めた（図３）．気管支内視 鏡検査では気管入口部がほぼ全周性に狭窄していた （図 4)。また胸部 CT 検查にて多発性肺転移を認めた
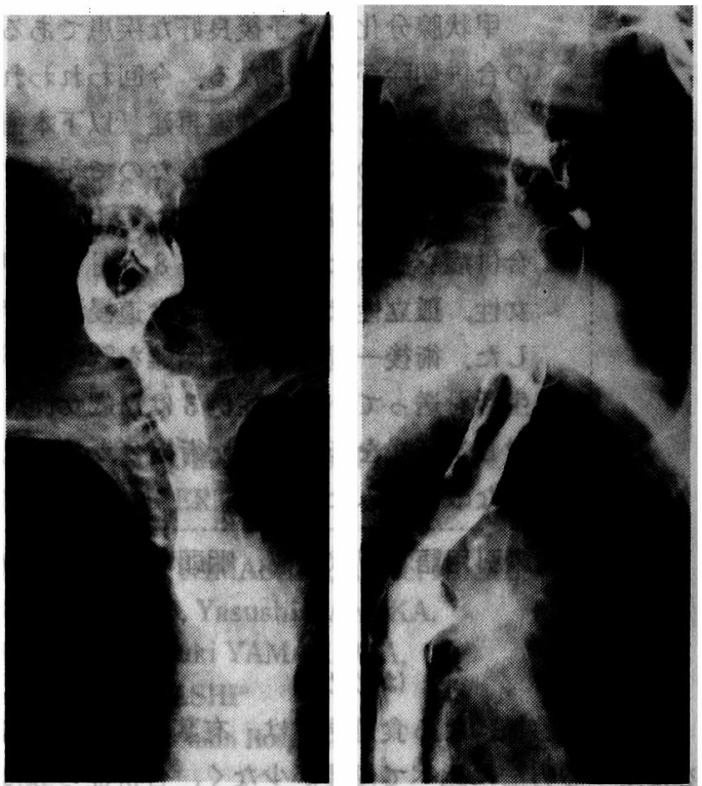

图 3 術前咽頭食道造影検查：下咽頭, 䫫部食道は腫 湯により压排されている。

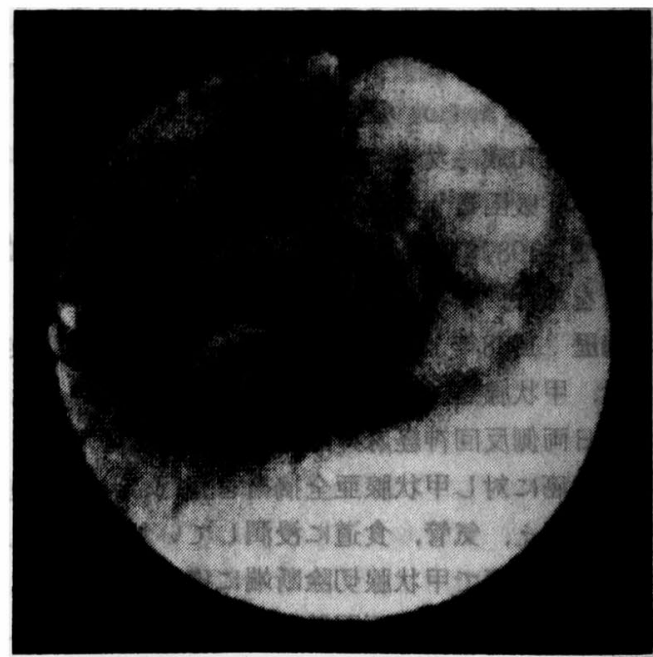

図 4 気管支内視鏡模査：気管入口部に全周性の狭窄 を認める。 
（図 5 ）、以上の検査より多発性肺転移を伴う，気管食 道に浸潤した甲状腺癌 (JT4，JN1，M1) と診断， 1992 年 2 月 5 日本術式を施行した。リンバ節郭清は施行乙 なからた。術後の食道造影検査では，吻合部に狭窄や 縫合不全は認められず，造影剂の通過は良好であった （図6)。術後には呼吸困難は消失し, performance statusの著明な改善を見た。

$$
\text { 考察 }
$$

甲状腺分化癌は発育増殖が緩慢で，周囲組織への浸

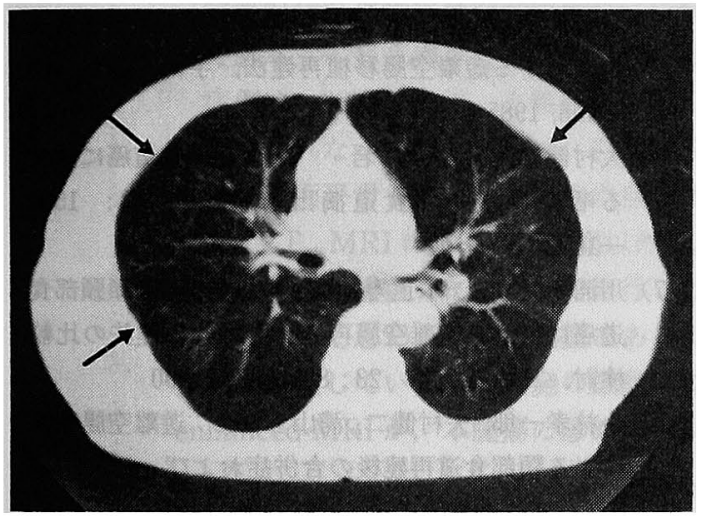

図 5 胸部 CT 検查：多発性肺転移（矢印）を認める。

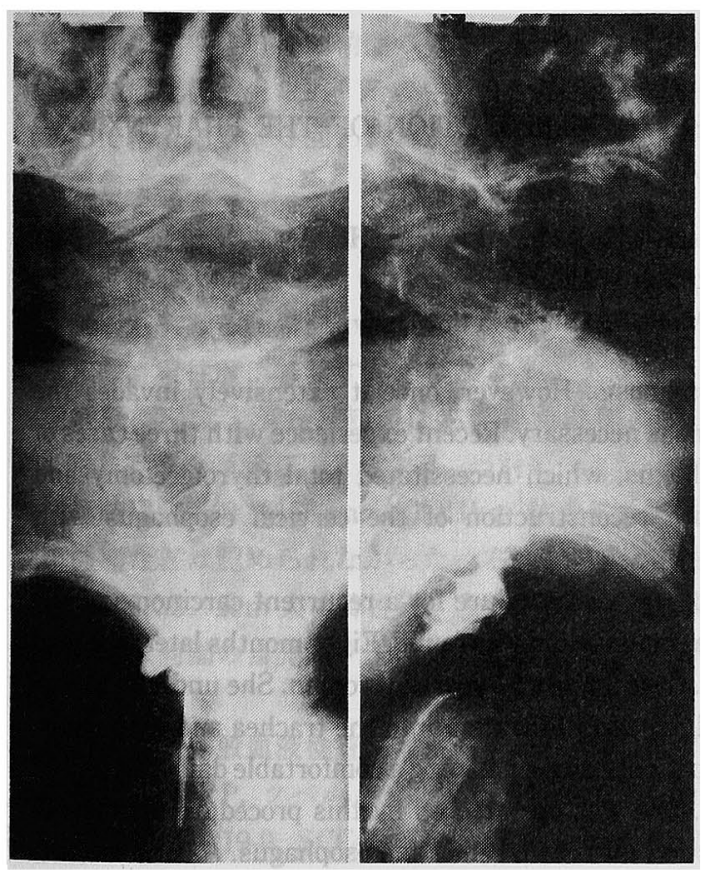

図 6 術後咽頭食道造影検査：吻合部涨窄や縫合不 全を認めず，造影剂の通過は良好である。
潤が比較的少ない予後良好な佚患である。一側腺葉に 限局した甲状腺分化湂には患側腺葉のすべてと峡部と 反対側腺葉の下 3 分の 1 を一括して摘除する甲状腺亜 全摘を標準的手術とする施設が多い1．隣接臓器浸潤 の中では気道へのものがとりわけ重要であり，予後を 規定する重要な因子といわれている2). 従来, 気管喉頭 浸潤に対してはその部分切除や電気メスによる焼却等 が行われていたが，局所再発予防の観点から積極的に 両者の部分切除を勧める意見もある 患とはい光，広範な浸潤を認める場合，安易な藏器温 存はか壳って quality of life（QOL）を損なら事にな りかれない，われわれは気管及び喉頭に広範に浸潤し た甲状腺分化癌に対しては甲状腺全摘術に喉頭全摘術 を合わせ行っている。

喉頭気管とともに頸部食道に浸潤を認める場合，同 様にその切除と再建法が問題となる，外膜までの浸潤 であれば切除後特別な修復を必要としない，また，筋 層に達していてb粘膜を損傷しないように留意し，切 除後に筋層欠損部を縫合するのみで十分である。しか し, 1/2周以上K及ぶ広範な浸潤例には頸部食道の合併 切除が必要となる゙

甲状腺分化癌は本術式を施行する場合，予後良好な 疾患に対する手術としては侵襲，続発する機能欠落之 もに過大ではないかとの異論もあろう。また，遠隔転 移を有する症例にはその延命効果が問われることにな る. しかし気道狭窄や食道狭窄はQOLを著しく損ね るのみならず，放置すれば短期間に確実に死に至るこ と, 甲状腺癌の遠隔転移は, 他の悪性腫瘍の転移に比 較して増殖が緩慢であり，長期の生存が期待できるこ となどを考光合わせ，気管，喉頭及び食道に広範に浸 潤している甲状腺癌には，たとえ遠隔転移の存在が判 明していてる本術式は許容されるものと思われる。今 回報告した 3 例のうち 1 例は，綎隔リンパ節再発によ る気管王迫により術後 8 カ月で失った。本例の切除標 本の検索では，輪状軟骨直下の気管に全周性の癌の浸 潤を認めたのみならず，頸部食道には高度の狭窄がみ られ，手術による延命効果と QOL 改善効果はあった ものと思われた。

頸部食道の再建法には，胸部食道を抜去した後，腹 腔より有荎腸管を挙上する方法と，頸部の局所に沶い て切除後に失われた食道の連続性を回復する方法とが ある。後者は筋皮弁を用いる方法と遊離腸管を移植す る方法に大別される。われわれは1983年以来，下咽頭 頸部食道癌手術の頸部食道再建に遊離空腸移植を採用 
し，その安全性を報告してきだ)ー7!。

今回提示した 3 例についても，術後合併症は認めず

順調に経過した。

遊離空腸移植は安全であるばかりでなく，筋皮弁と 比較して晚期の吻合部察発生率が低い，われわれが これまでに遊離空腸移植を施行した31例で,ブジーを. 要する狭窄は 2 例にみられたのみであった，またこ れら 2 例はいずれも自動吻合器を用いて端側に空腸食 道吻合を行った症例であった，従って最近では空腸食 道吻合は端々の Gambee 艇合, もしくは層々梿合とし ている、また，遊離空腸移植後の症例に対しアンヶー ト方式でQOLについて調查を行ったところ，身体的， 心理的健康状態は良好に保たれ，かつ社会的にる健全 な適応がなされている事が判明しだ).

$$
\text { おわりに }
$$

甲状腺分化癌は予後良好な疾患であるが，気管や頸 部食道に厇範に浸閏した症例にはそれらの合併切除が 必要となる。かかる場合, 安全で確実な食道再建法の 選択が望まれるか，適離空腸移植は少ない侵裝で施行 でき重篤な合併症の頻度が低いばかりでなく，術後の quality of lifeについてむ十分に满足できる術式であ ると思われた。

文献

1）藤本吉秀：甲状腺の腫湯，木本諴二他，新外科学
大系，15巻，甲状腺・上皮小体の外科，中山書店， 東京, 1989, p166-168

2）石原恒夫，山崎史朗，小林絋一他：気管合併切除を 要した甲状腺癌の治療, 日外会誌 $82: 973-976$, 1981

3）河西信勝, 内田正興, 鎌田信说他：甲状腺癌進行例 及び再発例の手術こその 2, 手訹 $12: 1563-1570$, 1982

4）兵田弘巳，佐々木文章, 秦 温信他：喉頭・気管合 併切除を施行した甲状腺分化癌症例の検討，日臨 外会誌 $51: 23-28,1990$

5）平野誠, 川浦幸光, 遠藤将光他：下咽頭頸部食道 癌に対する遊離空腸移植再建法, 手術 39：455 $-458,1985$

6）大村健二, 浦山 博, 岩喬：䁰部食道癌に対す る咽頭搌頭顠部食道摘出術, 手術 43：1599 $-1602,1989$

7）川浦幸光, 佐々木正寿, 大村健二他：下咽頭頸部食 道癌に対する遊離空腸再建法と胃管再健法の比較 検討, 日消外会誌 $23: 821-826,1990$

8）小林孝一郎, 大村健二, 浦山 博他：遊離空腸移植 による頸部食道再建後の合併症および quality of life，日消外会誌 $24: 951-955,1991$

\title{
THREE CASES OF THYROID CARCINOMA NECESSITAING RESECTION OF THE PHARYNX, LARYNX, AND CERVICAL ESOPHAGUS
}

\author{
Tamotsu YASUDA, Kenji OMURA, Hiroshi URAYAMA, Fumio ISHIDA, \\ Kazuyuki KAWAKAMI and Yoh WATANABE \\ First Department of Surgery, School of Medicine, Kanazawa University
}

Differentiated carcinoma of the thyroid has a good prognosis. However, once it extensively invades the surrounding organs, associated excision of the involved organs is necessary. Recent experience with three cases of thyroid carcinoma invading the trachea and cervical esophagus, which necessitated total thyroidectomy and resection of the pharynx, larynx, cervical esophangs, with reconstruction of the cervical esophagus with transplantation of free jejunum, is described here.

Case 1 was a 70-year-old woman. She underwent this operative procedure for a recurrent carcinoma of the thyroid invading the trachea and esophagus. No postoperative complication was found. Eight months later, she died of recurrence in the mediastinum from the thyroid carcinoma. Case 2 was a 57 -year-old woman. She underwent this procedure for thyroid carcinoma with solitary lesion in the lung and infiltration into the trachea and esophagus. After the operation a transient dysphagia was observed. The patient has been having a comfortable daily life, as of 3 years after the operation. Case 3 was a 74-year-old woman. She was operated on by this procedure for thyroid carcinoma with multiple metastasis in the lung and infiltration into the trachea and esophagus. As of 2 months after the operation, dyspnea disappears and remarkable remission in performance status has been noted. 